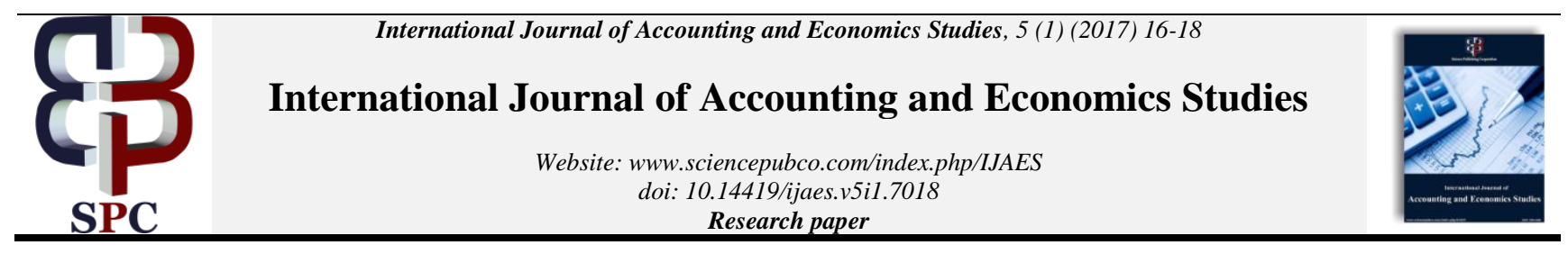

\title{
Development expenditure, fiscal consolidation and public revenue in India
}

\author{
Subramanya Venkataraman ${ }^{1 *}$, Arabi Urmi ${ }^{2}$ \\ ${ }^{1}$ Research Scholar, Department of Economics, Mangalore University, Mangalagangotri-574119, Karnataka State, India \\ ${ }^{2}$ Professor and Research Guide, Department of Economics, Mangalore University, Mangalagangotri - 574119, Karnataka State, India \\ *Corresponding author E-mail: subbu.paduvary@gmail.com
}

\begin{abstract}
Following challenges with increasing fiscal deficit, the Government of India adopted the path of fiscal consolidation with the sole intention of reducing fiscal and other deficits. However, in the drive to reduce government expenditure, it is necessary to be cautious of how it affects expenditures such as development expenditure that are very essential to the well-being of people. This study therefore investigated how fiscal consolidation and Public revenue affect development expenditure in India using time series data from 1977-2015 and the ARDL model. The study found that, in both the short run and long run, public revenue had a positive significant impact on development expenditure whiles fiscal consolidation had a negative significant impact on development expenditure. The study therefore recommended that in our attempt to attain fiscal consolidation, care must be taken not to abandon development expenditure which has serious effects on the well-being of people.
\end{abstract}

Keywords: ARDL; Development Expenditure; Fiscal Consolidation; Public Revenue; India.

\section{Introduction}

Most Governments in the world have a common goal of bettering the livelihoods of their citizens by ensuring economic growth and hence economic development. Due to this, some governments try to embark on increasing public expenditure in order to propel economic growth which is a pre requisite for economic development. However, there seems to be a trade of between rising government expenditure which would increase economic growth on one hand and worsening fiscal deficit on another hand if government revenue generation does not match up to the rising expenditure. This has led to various governments struggling to battle fiscal deficit which could be harmful to the strength of the economy. In India, there were similar challenges with rising fiscal deficits in the late 1980s and early 1990s. The situation was too bad to the extent that government could not pay for 2 weeks of imports. Given this, various reforms including fiscal consolidation were adopted which helped in the early 90s but stalled after 1997-98 leading to the re-emergence of rising deficit. This therefore led to the Introduction of the Fiscal Responsibility and Budget Management (FRBM) Act 2003 to deal with the worsening fiscal deficit. The act targeted fiscal deficit of $3 \%$ of GDP and $0.3 \%$ of GDP yearly by the Central government by 2008-09. This was followed by some amendments in 2012 and the finance Act 2015 (Rustagi, 2016).

However, with government concentrating on reducing fiscal and revenue deficits, this paper contends that certain restraints must be exercised in order not to badly affect development expenditures such social services and education services which are essential to the livelihoods of people. Based on this, this study therefore investigated how the FRBM Act 2003 and subsequent reforms (which are referred to as fiscal consolidation in this study) as well as public revenue have impacted on development expenditure in India.

\section{Literature review}

The theoretical literature that could be linked with this study has to do with how rising public spending or fiscal deficit affects economic growth.

Here we can talk of basically the Keynesian views, the classical and neo classical views and the neo-Ricardian views. The Keynesian school contends that fiscal deficit emanating from a proper policy design could propel economic growth by "crowding in" the private sector. On the other hand, the classical and neo classical views contend that huge fiscal deficits may end up "crowding out" the private sector which is not good for the economy. However, the neo-Ricardian views believe that the impact of rising public investment on the economy is neutral (Kumar \& Soumya, 2010).

On the empirical literature, Khundrakpam (2003) in India found that the long-run positive effect of public sector spending on national income would be deleterious if the growth of the public sector spending is excessive. Altaf and Khan (n.d) in Assam (India), for the period 1981-82 to 2006-2007 found that, in the long run, the share of revenue expenditure in Gross State Domestic Product (GSDP) and share of total government expenditure had positive significant impacts on GSDP. Mallick (2008) revealed that capital and aggregate expenditures didn't have any significant effect on economic growth with revenue expenditure explaining the variations in economic growth in a positive direction to some extent in India. Nurudeen and Usman (2010) in Nigeria found economic growth to be increased by government expenditure on communication, health and transport with total recurrent expendi- 
tures, government total capital expenditure and government expenditure on education having negative effects on economic growth. Tamang (2011) found a long run relationship between education expenditure and economic growth in India. Muhammad, $\mathrm{Xu}$ and Karim (2015) found no long run relationship between expenditure and economic growth in Pakistan. Nkechukwu and Okoh (2015) found positive and negative long run relationships between economic growth and capital expenditures on road and education and between economic growth and capital expenditures on health and agriculture in Nigeria respectively. Taoheed and Edame (2015) found significant relationship in a positive direction between economic growth and total government expenditure on health and transport in Nigeria. Giri and Mohapatra (2016) found that in the long run, development expenditure had a positive significant impact on economic growth in India. However, revenue expenditure and non-development expenditure were insignificant. However all the works above rather investigated how public expenditure affects economic growth and not how fiscal consolidation, public revenue and total expenditure affect development expenditure. Thus to the best of our knowledge, this study is novel in the sense that it is the first to study the impact of fiscal consolidation, public revenue and total expenditure on development expenditure in India.

\section{Methods}

\subsection{Data}

The study used time series data from 1977-2015 on India extracted from the Reserve Bank of India and Ministry of FinanceGovernment of India to achieve its objective.

\subsection{Empirical estimation techniques}

The study adopted the Augmented Dickey Fuller and the Philips Perron tests for unit root to test for the stationarity of the variables in order to avoid spurious regression since literature has shown that most time series variables are non-stationary. After establishing that none of variables was integrated of order 2 (I(2)), we adopted the Autoregressive Distributed Lag (ARDL) model in order to find out the short run and long run impact of fiscal consolidation, public revenue and total expenditure on developmen expenditure in India. We therefore specified our empirical estimation equations as below:

$\mathrm{DE}_{\mathrm{t}}=\emptyset_{0}+\emptyset_{1} \mathrm{TE}_{\mathrm{t}}+\emptyset_{2} \mathrm{PR}_{\mathrm{t}}+\emptyset_{3} \mathrm{dummy}_{\mathrm{t}}+\mu_{\mathrm{t}}$

Where, DE is development expenditure which is the dependent variable, TE is total expenditure, $\mathrm{PR}$ is public revenue, dummy variable takes the value of 0 for pre FRBM period and 1 for the FRBM/post FRBM periods (fiscal consolidation) and $\mu$ is random error term. All variables were in logarithmic forms except the dummy variable. We therefore re-specified (1) within the ARDL framework in a conditional error correction form to find out the long run relationship between fiscal consolidation, public revenue, total expenditure and development expenditure in India as follows:

$\Delta \mathrm{DE}_{\mathrm{t}}=\gamma+\sum_{\mathrm{i}=1}^{\mathrm{s}} \mho \Delta \mathrm{DE}_{\mathrm{t}-\mathrm{i}}+\sum_{\mathrm{i}=0}^{\mathrm{s}} \Phi_{\mathrm{n}} \Delta \mathrm{M}_{\mathrm{t}-\mathrm{i}}+\delta_{1} \mathrm{DE}_{\mathrm{t}-1}+$ $\delta_{\mathrm{n}} \mathrm{M}_{\mathrm{t}-1}+\mu_{\mathrm{t}}$

$\mathrm{DE}$ is as defined already, $\Delta$ is a difference operator, $\mathrm{n}$ is the number of regressors, $s$ is the optimal lag length, $M$ is a vector of observations of independent variables, $\gamma$ is intercept and $\mu_{t}$ is the error term.

\section{Results and discussion}

\subsection{Unit root results}

Table 1: Augmented Dickey-Fuller (ADF) and Philips Perron (PP) Tests for Unit Root

\begin{tabular}{lllll}
\hline \multirow{2}{*}{ Variable } & Log Levels & & \multicolumn{2}{l}{ First Difference } \\
& ADF Test & PP Test & ADF Test & PP Test \\
& t-statistic & Adj.t-statistic & t-Statistic & Adj.t-statistic \\
\hline LNDE & -1.977136 & -2.131208 & $-6.484586^{\mathrm{a}}$ & $-6.491021^{\mathrm{a}}$ \\
LNTE & -1.294170 & -1.294170 & $-6.441583^{\mathrm{a}}$ & $-6.441220^{\mathrm{a}}$ \\
LNPR & -1.352836 & -1.728959 & $-6.227670^{\mathrm{a}}$ & $-6.225368^{\mathrm{a}}$ \\
\hline
\end{tabular}

Source: Author's computation, Note: a, b, c denotes significance at $1 \%$, $5 \%$ and $10 \%$ level, respectively.

From Table 1, it can be seen that none of the variables was I(2) and hence we proceeded with the ARDL con-integration technique since it is capable of handling whether all variables are $\mathrm{I}(0)$ or all are I(1) or a mixture of both.

\subsection{Cointegration results}

Table 2: ARDL Bounds Cointegration Results F-Statistic $=8.087$

\begin{tabular}{lll}
\hline K (no of regressors) & Percentage & Critical Values \\
\hline & & $\mathrm{I}(0) \mathrm{I}(1)$ \\
3 & $10 \%$ & 2.723 .77 \\
3 & $5 \%$ & 3.234 .35 \\
3 & $1 \%$ & 4.295 .61 \\
\hline
\end{tabular}

Source: Author's computation

Since the F-statistic (8.087) was greater than all the upper bound values at $10 \%, 5 \%$ and $1 \%$, we rejected the null hypothesis of no cointegration and hence proceeded with our ARDL model.

\subsection{Regression results}

Table 3: ARDL Results on Development Expenditure, Fiscal Consolidation and Public Revenue in India

\begin{tabular}{llll}
\hline Variable & Coefficient & Standard Error & P-Value \\
\hline ECM & -.2975397 & .0727746 & 0.000 \\
LNDE & & & \\
Long Run & .2827662 & .2020133 & 0.171 \\
LNTE. & .7414265 & .2378828 & 0.004 \\
LNPR. & -.1744303 & .0955046 & 0.077 \\
Dummy & & & \\
Short Run & .0841342 & .0674223 & 0.221 \\
LNTE D1. & .2206038 & .0818039 & 0.011 \\
LNPR D1. & -.0519 & .0282168 & 0.075 \\
Dummy D1. & -.1322512 & .1203211 & 0.279 \\
Constant & & &
\end{tabular}

Source: Author's computation

Breusch-Godfrey LM Test for Autocorrelation:

Ho: no serial correlation, chi $2=0.134$ Prob $>$ chi $2=0.7142$

Breusch-Pagan / Cook-Weisberg test for heteroskedasticity:

Ho: Constant variance, chi2 $(1)=0.11$, Prob $>$ chi $2=0.7440$

The absence of autocorrelation and heteroskedasticity showed the robustness of our results and hence form table 3, the speed of adjustment (ECM ) in order to get back to equilibrium after a shock was significant at $1 \%$ and approximately $0.30 \%$ (-.2975397). The speed of adjustment was comparatively slower and thus after a shock, it took some time for the model to get back to equilibrium.

From the long run results, total expenditure was insignificant. With regards to public revenue, its coefficient of .7414265 was significant at $1 \%$ and hence a $1 \%$ increase in public revenue led to a $0.74 \%$ increase in development expenditure in India. On the fiscal consolidation indicator (dummy variable), its negative coefficient of -.1744303 was significant at $10 \%$ implying that a unit rise in the FRBM/post FRBM periods led to a $0.17 \%$ fall in development expenditure. Therefore the fiscal consolidation indicator (the FRBM and post FRBM periods) had a negative impact on development expenditure in India.

In the Short run, total expenditure was still insignificant. Further, public revenue had a coefficient of .2206038 that was significant at $5 \%$ and hence an increase in public revenue led to a $0.22 \%$ increase in development expenditure in India in the short run. On the fiscal consolidation indicator (the FRBM/post FRBM dummy variable), it was found that a unit rise in the FRBM/post FRBM period led to a $0.05 \%$ fall in development expenditure. Thus fiscal 
consolidation had a negative impact on development expenditure both in the short run and long run.

\section{Conclusion}

From the results, it can be concluded that whiles fiscal consolidation decreased development expenditure; public revenue increased development expenditure. Therefore in Government of India's attempt to attain fiscal consolidation, care must be taken not to abandon development expenditure which has serious effects on the well-being of people.

\section{References}

[1] Altaf, N. \& Khan, S. (n.d). Impact of Government Expenditure on Economic Growth in Assam: An Econometric Study. Department. of Economics, Gauhati University, Guwahati-781014, Assam.

[2] Giri, A.K. \& Mohapatra, G. (2016). .The composition of public expenditure and economic growth in India: Evidence from auto regressive distributed lag approach. Journal of Economic Research 21, 205-230.

[3] Khundrakpam, J.K (2003). Public Sector Spending and Economic Growth in India. MPRA Paper No. 51105, posted 1 November 2013 14:52 UTC.

[4] Kumar, R. \& Soumya, A. (2010). Fiscal Policy Issues for India after the Global Financial Crisis (2008-2010). ADBI Working Paper No. 249. https://doi.org/10.2139/ssrn.1678419.

[5] Mallick, H. (2008). Government Spending, Trade Openness and Economic Growth in India: A Time Series Analysis. Centre for Development Studies, Thiruvananthapuram, Kerala, India. Working paper no. 403.

[6] Muhammad, F., Xu, T. \& Karim, R (2015). Impact of Expenditure on Economic Growth in Pakistan. International Journal of Academic Research in Business and Social Sciences, 5(2). https://doi.org/10.6007/IJARBSS/v5-i2/1480.

[7] Nkechukwu, G.C. \& Okoh, J.I. (2015). Capital Expenditure at Disaggregated level and Economic Growth in Nigeria: An Empirical Analysis. International Journal of Science and Research (IJSR), 4 (6).

[8] Nurudeen, A., \& Usman, A. (2010).Government Expenditure and Economic Growth in Nigeria, 1970-2008: A Disaggregated Analysis. Business and Economics Journal, BEJ-4.

[9] Rustagi, P. (2016). Fiscal Responsibility and Budget Managemen (FRBM) Act. Indian Economic Service. Accessed on 23/11/2016 from:

http://www.arthapedia.in/index.php?title=Fiscal_Responsibility_an d_Budget_Management_(FRBM)_Act.

[10] Tamang, P. (2011). The Impact of Education Expenditure on India's Economic Growth. Journal of International Academic Research, 11(3).

[11] Taoheed, A. A. \& Edame, G.E. (2015). An Analysis of Government Spending and Economic Growth in Nigeria. International Journal of Development Research, 5(6), 4876-4882. 